\title{
Prevention and
}

\section{Management of Marine Pollution in Malacca Strait through the Littoral States Cooperation}

\author{
Nanik Trihastuti* \& Stephanie A. Putri ${ }^{* *}$ \\ \& Pulung W. H. Hananto***
}

Differences between the littoral states regarding the status of the Malacca Strait result in disharmony and inconsistencies in handling spatial planning and preventing marine pollution in the strait. International cooperation with user countries carried out so far is also not optimal due to conflict of interests. Using a normative juridical approach and secondary data of the provisions of United Nations Convention on the Law of the Sea (UNCLOS) 1982 and the Declaration of the Three Strait States, the Malacca Strait is under the sovereignty of the littoral states and used for international navigation with transiting passage. Spatial planning in the Malacca Strait, which results in overlapping uses for cross-fishing vessels, conservation, and traditional fishing, cannot be performed because the problem of maritime boundary determination has not been resolved by the littoral states. Tripartite cooperation needs to continue to be built through agreements

* Associate Professor of International Law at Diponegoro University, Semarang; Chairman of Law Scholar Association, Local Chapter of Central Java, Indonesia, S.H. (Diponegoro University), M.H. (Diponegoro U.), Ph.D. (Padjajaran U.). ORCID: https://orcid.org/0000-0003-0377-8259. This research was supported by the Faculty of Law Diponegoro University. The views reflected in this article, however, are the author's own. The author may be contacted at: naniktrihastuti@lecturer.undip.ac.id / Address: Faculty of Law, Diponegoro University, Jl. Prof. Soedarto, SH, Tembalang, Semarang 50275, Central Java, Indonesia.

** Ph.D. candidate at the University of Wollongong School of Law, Australia. S.H./M.H. (Diponegoro U.). ORCID: https:// orcid.org/0000-0001-7980-6338. The author may be contacted at: sap993@uowmail.edu.au/Address: Northfields Avenue, Wollongong, NSW, Australia 2522.

*** Lecturer and Researcher at the Faculty of Law Diponegoro University, Semarang; Specialist Advisor at Free Trade Agreement (FTA) Center, Indonesia. S.H./M.H. (Diponegoro U.), LL.M. (National U. Malaysia). ORCID: https:// orcid.org/0000-0003-4658-2184. The author may be contacted at: hananto.pulung@live.undip.ac.id/Address: Faculty of Law Diponegoro University, Jl. Prof. Soedarto, SH, Tembalang, Semarang 50275, Central Java, Indonesia. All the websites cited in this article were last visited on November 1, 2020. 
that not only bind the littoral states but also the user states.

\section{Keywords}

Optimization of Cooperation, Malacca Strait, Littoral States, Marine Pollution

\section{Introduction}

As a strait used for international navigation, the Malacca-Singapore Strait is narrow, windy, and crowded with a shallow level of less than $23 \mathrm{~m}$. The capacity of the strait is not fully accommodating giant tanker ships because they becoming bigger and longer. This shallowness is very dangerous for giant ships with a load of more than $19 \mathrm{~m}$. In the section of the Singapore Strait that is only $1.7 \mathrm{~km}$ wide, only $1.3 \mathrm{~km}$ can be traversed, whereas in the Philip Channel, only about $800 \mathrm{~m}$ wide can be navigated. Sea currents in the Malacca Strait can reach speeds of 3 nautical miles (nm) with irregular changes in speed. Consequently, the Malacca Strait has the highest number of sea accidents in the world. In the period 1970-2015, no less than 200 cases of ship collisions occurred in the Malacca Strait, some of which involved large vessels. If an oil spill occurs, then it will reach a sensitive area within a matter of hours. ${ }^{1}$ For the record, the sea currents in the Malacca Strait are quite swift, averaging about $5 \mathrm{~nm}$ per hour (knots), and the current direction depends on time or season. This means that the territorial waters of the strait can possibly return to "clean" quickly if an oil spill occurs or hazardous and toxic materials are found in the Malacca Strait because the oil spill is carried by ocean currents and waves caused by ships passing by. ${ }^{2}$

The high activity of ship traffic also increases siltation in the Malacca Strait, not only because where the sea still functions as the largest trash bin in the world for the dumping of garbage from ships to the sea, but also because no facilities for garbage disposal from ships exist in the cities passed by or visited by foreign ships. The density of ship traffic in the Malacca Strait, in addition to the difficultly for coastal countries bordering the strait to utilize its natural resource potential, will also jeopardize the national security interests of the countries bordering the strait. ${ }^{3}$

1 N. Isfarin, \& M. Triatmodjo, International Cooperation on Marine Environment Protection of Oil Pollution from Vessel (a Study of Straits Malacca and Singapore), 12(4) Indon. J. Int'L L. 508-37 (2014).

2 C. Thia-Eng et al., The Malacca Straits, 41(1-6) Mar. Pollution Bull. 160-78 (2000).

3 E. Pratomo, Indonesia-Malaysia maritime boundaries delimitation: a retrospective, 8(1) AUSTL. J. MAR. \& OCEAN 
Efforts to prevent, mitigate, and control marine pollution in the Malacca Strait through international cooperation were carried out by both littoral and user states including Japan. The first memorandum of understanding ("MoU") between Japan and three coastal states conducted preliminary and detailed hydrographic surveys, as well as development assistance for the Vessel Traffic Systems Project to create safe water areas for ships passing there. ${ }^{4}$ However, the results might not be optimal. One contributing factor is the differences in interests between Indonesia and Malaysia, on the one hand, and Singapore, on the other, which will result in differences in the way of viewing the existence of the Malacca Strait. ${ }^{5}$

In the Malacca Strait, Indonesia controls nearly $80 \%$ of the strait area, while Malaysia, with its very long beaches and the livelihoods of the people in the coastal area who still earn a living as fishermen, places more importance on the function of defending the environment to preserve fishery resources in addition to being a container communication. Thus, maintaining the function of the Malacca-Singapore Strait is expected to improve environmental sustainability in this area. Conversely, although the coast area is not too large, Singapore has become one of the largest ports in the world. Today, Singapore is a communication and shipping container center of the strait area. Thus, the internationalization of the Malacca Strait will be more profitable for Singapore. ${ }^{6}$

The efforts of Singapore and several user countries to make the Malacca Strait an international strait or high seas are a problem for Indonesia, because the efforts must guarantee a balance between the interests of maintaining sovereignty and those of the littoral and user states. In this course, the coastal states are very limited to occupy the Malacca Strait, because these waters are, in effect, no longer their territory. In those waters, the principle of "free transit" should be applied for a coastal country not so much, even if an event in these waters harmed it. Another problem causing inadequate handling and marine pollution is the "unclear" spatial distribution in the Malacca Strait by littoral states, which results in overlapping uses for cross-fishing vessels, conservation areas, and fishing traditional catches. ${ }^{7}$

4 Memorandum of Understanding on Phase Two of a joint Hydrographic Survey signed at 10th Co-operation Forum held on October 2-3, 2017 at Kota Kinabalu, Malaysia.

5 M. Valencia, \& A. Jaafar, Environmental management of the Malacca/Singapore straits: legal and institutional issues, 25(1) NAT'L RESOURCES J. 195-232 (1985).

$6 \mathrm{X} . \mathrm{Qu} \& \mathrm{Q}$. Meng, The economic importance of the Straits of Malacca and Singapore: an extreme-scenario analysis, 48(1) Transport Res E-Log 258-65 (2012).

7 GEF/UNDP/IMO Regional Programme (1998), Marine Pollution Management in the Malacca/Singapore Straits: Lessons Learned, Quezon City, Philippines: GEF/UNDP/IMO Regional Programme for the Prevention and Management 


\section{Status of the Malacca Strait and the Interests of the Periphery}

The Malacca Strait is a waterway connecting the high seas and territorial sea. It is an important and strategic international shipping lane. The strait is chimney-shaped; the widest part is located in the north between the islands of Weh and Krismus whose width reaches 300 miles. Conversely, the narrowest part is located in the southern part of the strait, 8 miles wide, namely, in Kukup (South Johor), which is the entrance to the Singapore Strait. The length of the Malacca Strait is $530 \mathrm{~km}$ with a minimum depth of $20 \mathrm{~m}$. In certain places, the depth only reaches 6-14 $\mathrm{m}$, and the minimum depth in the shipping lane is $25.6 \mathrm{~m}$. The current speed is $5 \mathrm{KTS}$; the widest strait section that can be navigated is $25.6 \mathrm{~m}$, and the narrowest is only 2.6 miles. Most of the Malacca Strait area is part of the territorial sea of two opposing coastal states, namely, Indonesia and Malaysia. ${ }^{8}$

Figure 1: Malacca Strait Map ${ }^{9}$

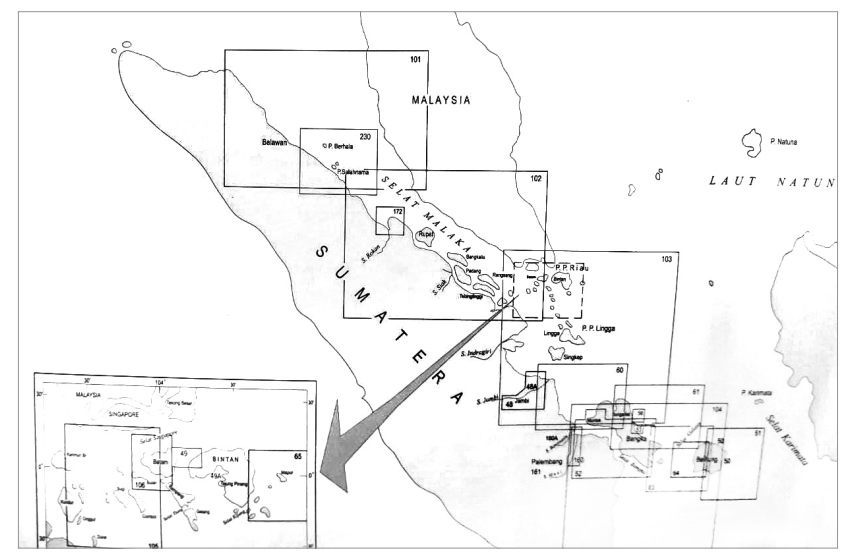

The UNCLOS regime regulates navigation activities through strait waters in every international shipping activity using the doctrine of transit passage rights. On

of Marine Pollution in the East Asian Seas.

8 H. Djalal, The Malacca Strait and Singapore Strait Problems [Persoalan Selat Malaka dan Selat Singapura], presented at a seminar on the Malacca Strait organized by the Deputy Minister of State for Policy Support on January 13,2006 at the State Secretariat of the Republic of Indonesia, Jakarta. (2006).

9 Center for Hydrography and Oceanography of the Indonesian Navy (PUSHIDROSAL), May 14, 2020. 
maritime highways, all forms of international shipping activities are permitted to conduct transit arrangements. ${ }^{10}$ Provisions for the right of transit also apply to warships carrying nuclear weapons and cargo ships containing dangerous goods. ${ }^{11}$ To do a transit cruise, three important aspects are needed to be considered: (1) the waters in question referring to the strait; (2) the strait waters, which are an international navigation area; and (3) a transit cruise. ${ }^{12}$

The geographical condition of the Malacca Strait, which connects the Indian Ocean and the South China Sea, provides opportunities for every ship to use this sea route on the basis of the right of transit. More than 70,000 ships pass through the Malacca Strait every year. ${ }^{13}$ Half of the world's oil flow and one-third of world trade are borne through this strait. Even East Asian countries such as China, Japan, and Korea rely on these water zones, because most of the trade and fulfillment of their domestic petroleum imports are distributed through this strait from the Middle East. $^{14}$

Nevertheless, the foreign ships freely passing through the Malacca Strait waters zone does not have positive impact on littoral states especially from economic and environmental aspects. According to Article 44 of the UNCLOS, the coastal states in the relevant strait waters do not have the authority to prevent the voyage of transit of foreign vessels. ${ }^{15}$ Article 34 of the UNCLOS regulates the legal status of waters, which are the straits used for international waters, as follows:

1. The regime of passage through straits used for international navigation established in this Part shall not in other respects affect the legal status of the waters forming such straits or the exercise by the States bordering the Straits of their sovereignty or jurisdiction over such waters and their air space, bed, and subsoil;

2. The sovereignty or jurisdiction of the States bordering the straits is exercised subject to this Part and to other rules of International law.

\footnotetext{
UNCLOS art. 27.

Id. art. 30 .

Id.

13 Directorate General of Sea Transportation, Indonesia officially serves scouting in the Malacca Strait and Singapore Strait 10 [Indonesia resmi layani pemanduan di Selat Malaka dan Selat Singapura], Ministry of Transportation of the Republic of Indonesia, Apr. 10, 2017, https://hubla.dephub.go.id/home/post/read/4751/indonesia-resmi-layanipemanduan-di-selat-malaka-dan-selat-singapura-10.

14 H. Ibrahim \& N. Khalid, Growing shipping traffic in the Strait of Malacca: Some reflections on the environmental impact, in Global Maritime and Intermodal Logistics Conference 3-7 (Singapore Maritime Institute of Malaysia, Dec. 17-18, 2007).

15 A. Ansari \& N. Kamal, Prevention, abatement and control of pollution of straits: an appraisal with special reference to the Straits of Malacca, 3(37) MaLayan L. J. (2005).
} 
Following these provisions, although the strait is used for international navigation, the legal statuses of other waters are not affected, in the sense that the littoral states can still exercise its sovereignty and jurisdiction in the strait waters.

In relation to the Malacca Strait, Article 34 indicates that the Malacca Strait are waters that are under the sovereignty and jurisdiction of the littoral states, because some parts of the strait are still within the territorial sea of the littoral states, including Indonesia, Malaysia, and Singapore. ${ }^{16}$ Furthermore, Article 35 of the UNCLOS stipulates:

(a) Any areas of internal waters within a strait, except where the establishment of a straight baseline in accordance with the method set forth in article 7 has the effect of enclosing as internal waters areas, which had not previously been considered as such

(b) The legal status of the waters beyond the territorial seas of States bordering straits as exclusive economic zones or high seas;

(c) The legal regime in straits in, which passage is regulated in whole or in part by long-standing international conventions in force specifically relating to such straits.

Article 35 clearly shows that the existence of internal waters is still recognized, except for the case of drawing a line to determine the internal waters to close the strait. In the Malacca Strait, the establishment of baselines to determine the position of internal waters of the littoral states does not cause closure of the strait, and the position of the Malacca Strait is unaffected by the delineation of straight baselines to determine internal waters, because internal waters are in the baselines. ${ }^{17}$

In addition, the exclusive economic zone (EEZ) is still recognized as the EEZ regime, which is the high seas in the end. Thus, although the Malacca Strait is used for international navigation, the EEZ of littoral states remain recognized. Article 36 of the UNCLOS states:

This part does not apply to a strait used for international navigation if there exists through the strait a route through the high seas or through an exclusive economic zone of similar convenience with respect to navigational and hydrographical characteristics; in such routes, the other relevant Parts of this Convention, including the provisions regarding the freedoms of navigation and overflight, apply. 
Hence, the Malacca Strait cannot be categorized as an international strait because the shipping routes in the Malacca Strait are not only through the EEZ, but also through the sea area of the littoral state. The territorial sea exists between the low-water line and EEZ. Thus, although the Malacca Strait has been used as a crossing for the voyage of many ships from the past, it cannot be said that the navigation regime in the Malacca Strait is subject to the regime of the high seas like freedom of navigation. Article 15 of the UNCLOS withdraws the median line from the outermost land area. It practically makes the Malacca Strait territorial waters of Indonesia and Malaysia. To protect the domestic interests of the coastal states, any activity of foreign ships passing through the Malacca Strait is required to comply with the provisions and regulations concerning shipping stipulated by the relevant states. ${ }^{18}$

With reference to the Malacca Strait topography, the three coastal states, namely, Indonesia, Malaysia, and Singapore, control the traffic in this waterway to prevent vessel accidents that will result in marine pollution. Additionally, this effort implies that the Malacca Strait is not an international strait. Therefore, in this maritime area, the right of transit passage must not be obstructed, except in certain circumstances. Freedom of navigation essentially means only the freedom to cross the Malacca Strait, accompanied by conditions as regulated in Article 39 of the UNCLOS. In addition, Article 42 of the UNCLOS grants authority to coastal states to make provisions relating to transit passage, such as provisions regarding shipping safety, prevention of pollution, supervision of foreign fishing vessels and efforts to prevent violations of customs rules. ${ }^{19}$

The different perspectives of the three littoral states toward the Malacca Strait impacted the collaborative efforts undertaken in tackling marine pollution in the Malacca Strait. For Indonesia and Malaysia, even if the Malacca Strait is recognized as their "territorial seas," shipping of foreign ships through these waters can only be permitted on an "innocent passage" basis, i.e., a way that does not harm the coastal states following the principles of "peace," "good order," and "security." 20 In this case, the coastal state is privileged with broader rights to regulate the strait, because the delimitation of the context the rights of innocence passage is determined by the coastal state. 


\section{Implications of Maritime Boundaries to Spatial Arrangements in the Malacca Strait}

The strategic position of the Malacca Strait can be seen from the perspectives of economy, military, and petroleum channel. These factors affect the national interests of the littoral states, in addition to those of the user state. Narrow and shallow water conditions, coupled with heavy traffic of ships, both passenger and cargo ships, or fishing vessels that cross the lane every day, pose a great risk of disaster, thereby increasing the safety and security of shipping in the Malacca Strait.

Hampered efforts to improve shipping safety and security in the Malacca Strait are mainly due to the unclear allocation of space/areas in the strait, such as the use of the Malacca Strait as an ammunition disposal site, the location of ship ballast water disposal, and zones underwater security. ${ }^{21}$ Due to the many things that must be considered, spatial planning in the Malacca Strait is not easy. These include the right of passage to foreign ships and the interests of the edge of the strait, which also needs to be protected for the fishermen around the strait who are currently experiencing difficulties in obtaining fish because of the damage to the marine environment in the Malacca Strait. It has been delayed by Indonesia mainly because maritime boundaries have not been settled down with Malaysia. ${ }^{22}$

Because Indonesia is not the only coastal country in the Malacca Strait, the Indonesian maritime boundary line is drawn in the middle of the Strait. In the Malacca Strait, a waterway exists within Indonesia's maritime territory measured $12 \mathrm{~nm}$ from the base line and is located less than $24 \mathrm{~nm}$ wide. Meanwhile, the Indonesian territorial watershed is located in the middle of the strait (median line). Applying the territorial sea width of $12 \mathrm{~nm}$ and using the principle of withdrawal of the median line by the two states of Indonesia and Malaysia, consequently, most of the waters of the Malacca Strait are part of the maritime territory of both states. To reinforce the sovereignty of the two countries in the region, Indonesia and Malaysia sign a treaty between relating to the delimitation of the Territorial Seas of the Two Countries in the Malacca Strait on March 17, 1970. The UNCLOS encouraged the two countries to amend the provisions of the delimitation of the Territorial Seas.

21 Management Center for Coastal \& Marine Resources, Marine Spatial Planning [Tata Ruang Laut], Coastal and Marine Resource Management Center (BPSPL) Ministry of Maritime Affairs and Fisheries of the Republic of Indonesia (2018), https://kkp.go.id/djprl/bpsplpadang/page/263-tata-ruang-laut.

22 E. Pratomo, \& J. Kwik, Good agreements make good neighbours: Settlements on maritime boundary disputes in South East Asia, 117 Marine PoL'y 103943 (2020). 
The issue of maritime boundaries between Indonesia and Malaysia was triggered by Malaysia's actions to publish two maps of its territory on December 21, 1979, which depicted the Malaysian Peninsula and Sabah/Sarawak complete with the continental runway between Malaysia and Indonesia. ${ }^{23}$

Figure 2: Malaysia Map of Sabah/Sarawak (1979) ${ }^{24}$

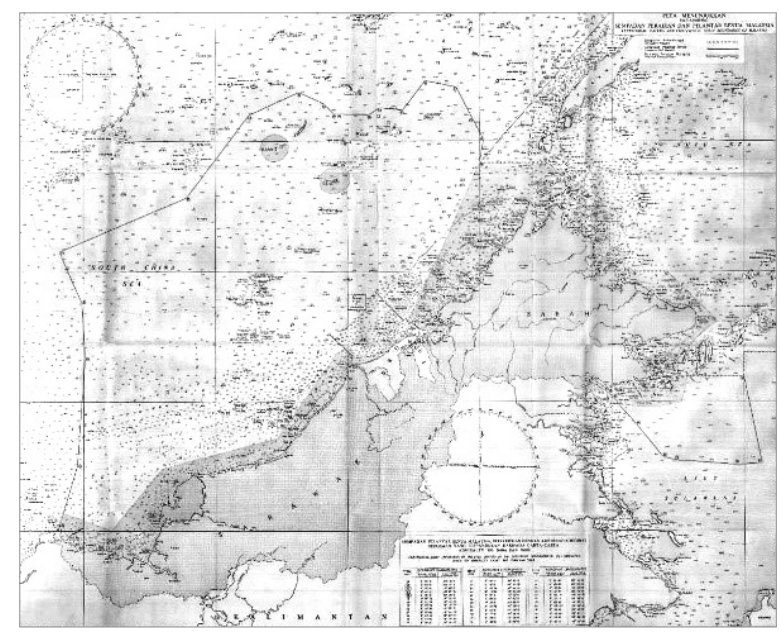

The map, which depicts the territory of Malaysia with a very excessive maritime claim, applied the principles of straight baselines for the archipelago, whereas, in accordance with Article 46 of the UNCLOS, Malaysia was not an archipelagic state. Because the straight baseline was applied between Jarak Island and Perak Island, which are $123 \mathrm{~nm}$ away from each other, ${ }^{25}$ and it will henceforth be a baseline to decide its territorial sea, part of Indonesia's EEZ is finally duplicated with the Malaysia's territorial sea. In addition, as the Horsburgh lighthouse, located at the entrance to the Singapore Strait from the East, was used as a base point, a maritime boundary issue arose between Indonesia and Malaysia, especially in the Singapore Strait between Bintan Island (Indonesia) and East Johor (Malaysia). Based on the maps issued by Malaysia, Malaysia's territorial sea boundary is $3.3 \mathrm{~nm}$ from Bintan

23 A. Adam, History of the Indonesian-Malaysia-Singapore Sea Border [Sejarah Perbatasan Laut Indonesia-MalaysiaSingapura], in Indonesia's Regional Border Problems with Malaysia And Singapore [Masalah Perbatasan Wilayah Indonesia Dengan Malaysia Dan Singapura] (J. Sitohang \& R. Yustiningrum eds., 2016).

24 Center for Hydrography and Oceanography of the Indonesian Navy (Pushidrosal).

25 Ministry of Maritime Affairs and Fisheries, National Border Area Study, Jakarta, Research Center for Marine Areas and Non-biological Resources, Maritime Research and Fisheries Agency (2002). 
Island. The 1979 Malaysia Map resulted in an overlap with Indonesian waters. ${ }^{26}$

Figure 3: Boundary Line in Malaysian Version ${ }^{27}$

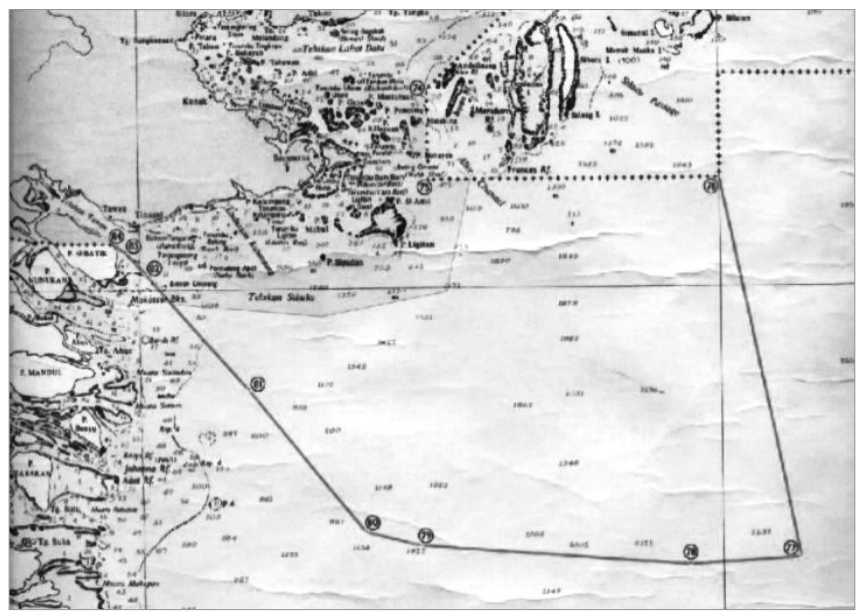

The unilateral issuance of Malaysia Map in 1979 had been protested by several countries bordering Malaysia, such as Singapore, the Philippines, Thailand, Vietnam, Brunei Darussalam, and Indonesia. The publicity was considered to concern the boundaries of several marine segments, including mixing of regulations on EEZ and continental shelf in the Malacca Strait.

For Indonesia, the 1979 map published by Malaysia in anticipation of what was then UNCLOS raised new problems during that time and impeded sea border negotiations that began in 1973 , which would have expected to be resolved in $1980 .^{28}$

The publication of the 1979 map was contrary to international law because it was unilaterally made by Malaysia. Based on Article 279 of the UNCLOS and Article 33, paragraph (1) of the UN Charter, the disputes of sea borders shall be settled through peaceful means like negotiations and treaties. Following protests from its neighboring states, the 1979 map was then withdrawn by Malaysia. Nevertheless, Malaysian claims regarding territorial waters still refer to the 1979 map.

26 I. Arsana, Mending the imaginary wall between Indonesia and Malaysia: The case of maritime delimitation in the waters off Tanjung Berakit, 13(1) WACANA 1-28 (2011).

27 Center for Hydrography and Oceanography of the Indonesian Navy (Pushidrosal), May 14, 2020.

28 A. Simanjuntak, Arif H. Oegroseno: Map of Malaysia with Protest from Many Countries [Arif H. Oegroseno: Peta Malaysia Diprotes Banyak Negara], TemPo, June 22, 2009, https://nasional.tempo.co/read/183050/arif-h-oegrosenopeta-malaysia-diprotes-banyak-negara. 
Malaysia's maritime zone boundary claims based on this 1979 map have been essentially injured by the treaty between the Republic of Indonesia and Malaysia relating to the Delimitation of the Territorial Seas of the Two Countries in the Malacca Strait 1970, which has bound Indonesia and Malaysia through their ratifications. ${ }^{29}$

The issue of overlapping EEZ areas between Indonesia and Malaysia in the Malacca Strait, which has yet to be resolved, is due to differences in principles in negotiating maritime boundaries. In this case, Indonesia tends to support that the EEZ boundary line should not coincide with the existing seabed boundaries and proposes the use of the equidistance line to establish EEZ equitable boundaries for both states. ${ }^{30}$ On the other hand, Malaysia seems to prefer single boundary line for the seabed and EEZ, as illustrated in its 1979 continental shelf map. For these reasons, there are territories where the two countries have overlapping EEZ claims, making it difficult to manage resources in the region, particularly in regulating spatial planning in the region. ${ }^{31}$

Figure 4: The overlapping territories of EEZ between Indonesia and Malaysia in the Malacca Strait ${ }^{32}$

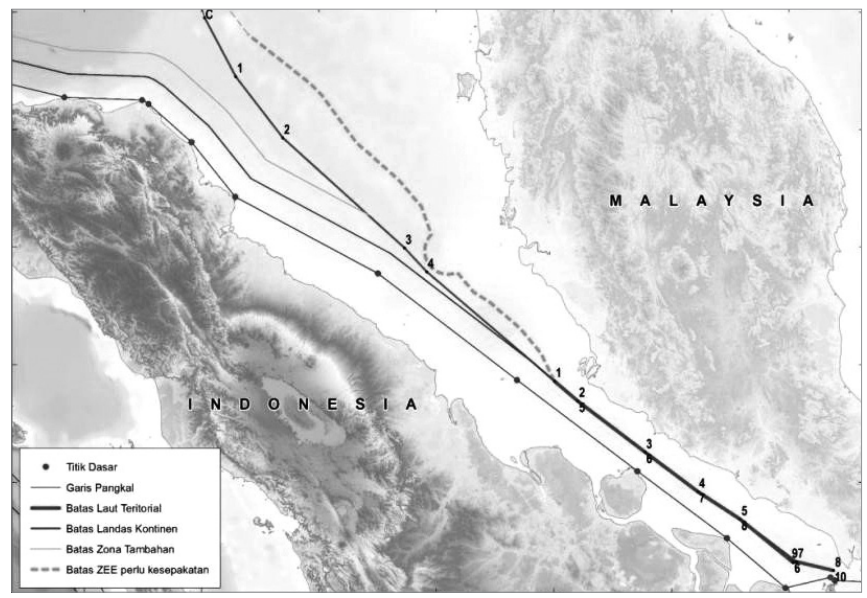

29 A. Oegroseno, Indonesia's maritime boundaries, in Indonesia Beyond the Water's Edge: Managing an ArchiPelagic State 49-58 (R. Cribb \& M. Ford eds., 2009).

30 UNCLOS art. 36.

31 Id.

32 T. Patmasari, E. Artanto \& A. Rimayanti, Recent Developments in Indonesia's Maritime Boundaries with Neighboring Countries [Perkembangan Terakhir Batas Maritim Indonesia dengan Negara Tetangga], Proc. Seminar Nasional GeomatiKa 03-21 (2016). 
Referring to Article 74 of the UNCLOS concerning the Delimitation of the Exclusive Economic Zone between States and Opposites or Adjacent Coasts, the two countries with a spirit of mutual understanding and cooperation should make every effort to arrange practical provisions. However, this effort will not affect the outcome of the boundary agreement in the future.

Article 74 is the only provision in the UNCLOS that explicitly regulates what actions must be taken by the states whose overlapping EEZ areas are still in the negotiation process. Such arrangements allow the states to exploit these overlapping territories and maintain normal relations. Without such interim arrangements, the states will argue overlapping territories to defend their jurisdiction and be able to exercise their sovereignty. ${ }^{33}$

On January 27, 2012, Indonesia and Malaysia made a temporary arrangement in the form of a MoU. ${ }^{34}$ Following this MoU, in the overlapping EEZ territories that have not yet reached a maritime boundary, the two states are prohibited from engaging in fishing, exploration and exploitation of natural resources. If fishermen from both states are found fishing in the overlapping territories, eviction is the only viable option. Although this MoU is not legally binding, its nature as an international agreement requires the parties to carry out the contents of the agreement based on the principle of pacta sunt servanda and good faith.

For Indonesia, first, legal and political issues regarding the Malacca-Singapore Strait are mainly to maintain sovereignty in the territorial zone up to $12 \mathrm{~nm}$ under the UNCLOS. Second, the agreement made between Malaysia and Singapore must be confirmed. Third, the provisions of international law that strike a balance between the interests of the littoral states and maritime countries should be maintained. Fourth, the unity and friendship between the three coastal states and neighboring countries in the ASEAN must be guaranteed. Fifth, defending the safety of shipping and the sustainability of its coast from increasingly large sea pollution, especially from giant tankers passing through the Malacca Strait, is crucial. ${ }^{35}$ Conversely, Malaysia's interest in defending its argument is based more on the prospective economic outlook of the potential of marine natural resources and the sustainability of the Malacca Strait in the future. This was demonstrated by the imposition of recognition of the

33 J. Charney, Progress in international maritime boundary delimitation law, 88 AM. J. InT'L L. 227-56 (1994).

34 Memorandum of Understanding between the Government of the Republic of Indonesia and The Government of Malaysia in Respect of the Common Guidelines Concerning Treatment of Fishermen by Maritime Law Enforcement Agencies of the Republic of Indonesia and Malaysia. MoU Common Guideline Indonesia-Malaysia (2012).

35 Supra note 8 . 
1979 map of Malaysia, which unilaterally determined. ${ }^{36}$

Especially for developing countries, clearly defined maritime boundaries are an essential measure to enforce fruitful foreign policy and effective sea management. ${ }^{37}$ Maritime boundary delimitation can thus be an effective way for a country to assert its sovereignty, rule of law, and legitimacy to neighboring countries. ${ }^{38}$ Delimitation also reduces the overlapping zones of maritime claims that demonstrate the potential to cause conflicts between neighboring countries, by eliminating sources of friction and disputes in international relations. ${ }^{39}$

Because maritime boundaries have not yet been agreed between Indonesia and Malaysia, they should jointly manage the Malacca Strait. As stipulated in Article 74 of the UNCLOS, which requires provisional arrangements to be made for territorial waters that have not yet been agreed upon by the EEZ, Indonesia and Malaysia can adopt a temporary measure before maritime zone boundaries between the two countries is signed.

\section{Prevention and Management of Marine Pollution in the Malacca Strait}

As mentioned above, the Malacca Strait is not an international strait, but a strait used for international navigation. This confirms the position of littoral states, especially Indonesia, as a state that demonstrates sovereignty in its territorial water with a claim of $12 \mathrm{~nm}$, as stipulated in Article 3, paragraph 2 of Law No. 6 of 1996 concerning Indonesian Waters. This shows that Indonesia applies its jurisdiction within its territorial boundaries over water, air, seabed, and subsoil, officially recognized by the UNCLOS. ${ }^{40}$ Conversely, the traffic density of shipping lanes, as a result of the increasing intensity of global trade through the Malacca Strait, is changing the status of the Malacca Strait into Sea Lines of Trade and Sea Lines of Communication. The

36 K. Anwar, Cooperation in the Management of the Malacca Strait: Facing the ASEAN Economic Community [Kerjasama Pengelolaan Selat Malaka: Menghadapi Masyarakat Ekonomi Asean] (1st ed. 2015).

37 J. Bailey, The unanticipated effects of boundaries: the Exclusive Economic Zone and geographically disadvantaged states under UNCLOS III. 5 BOUND. SEC. Bull. 87-95 (1997).

38 C. Schofield, Maritime Zones and Jurisdiction, in Proc. 2003 ABLOS Tutorials \& Conference Addressing Difficult ISSUES IN UNCLOS 28-30 (2003).

39 C. Schofield, Cooperative mechanisms and maritime security in areas of overlapping claims to maritime jurisdiction, in Capacity Building for Maritime Security Cooperation in the Asia-Pacific 8-11 (P. Cozens \& J. Mossop eds., 2005).

40 UNCLOS arts. 34-35. 
waterway along the Malacca Strait should be thus secured for every country in the world. For this reason, integrated management of the straits' countries is necessary to deal with a variety of security and safety issues regarding shipping in the Malacca Strait. It should be also maintained when dealing with the interests of the user state toward the Malacca Strait.

As the center of activity of the Malay world and other regions, the Malacca Strait has been historically important. ${ }^{41}$ Given this, the efficient management is no longer just for a private domain of the littoral state but for more prosperous world economy. On the other side, with the very frequent uses of the Malacca Strait for crossing ships, the negative impact, like marine pollution, threatens the human communities around the Malacca Strait. For this reason, a middle ground needs to be found to bring these two interests together by collaboration. Because the Malacca Strait issue is not only concerned with environmental issues, but also security and economic issues, cooperation based on international law must be mutually beneficial.

The conservation and protection of the marine environment is an obligation that is inherent in every country. In addition to conducting consultations on marine natural resources, the state has the responsibility to carry out maintenance by controlling and lending the sea. Important steps must be taken by each country either unilaterally or multilaterally to the potential arising from the presence of marine pollution. Articles 207-212 of the UNCLOS specify the prevention, reduction and control pollution of the marine environment from land bases, seabed activities, activities in the area, transportation sources, and ship bases. The source of pollution must be considered, predicted, and controlled by each strait country, who can impose domestic laws to enforce the provisions of international law on the sea and environment. ${ }^{42}$

In matters of security, the littoral state plays an important role of being responsible for securing the Malacca-Singapore Straits waters. The user state is not required to involve itself in a "safeguarding" effort by fielding troops in the region, but can only contribute to the security of this area through capacity-building cooperation. This commitment must be explicitly stated, because there remain efforts by Singapore to internationalize the Malacca Strait. Singapore opens its position to other countries for the participation in the Malacca-Singapore Straits region development.

The hot pursuit mechanism is applied by permitting strait edge's state patrols to enter the water edge area of other countries, which must be done with notice as soon

41 A. Abdullatif, History in the Straits of Malacca [Sejarah Di Selat Malaka] (1984).

42 P. Hananto, Current Developments of Legal Instruments to Prevent and Control of Pollution in the Malacca Strait, 2(4) Adm. L. Gov. J. 721-32 (2019). 
as possible in case of violation of law. ${ }^{43}$ To cover these actions, it is necessary simplify the bureaucratic permit to be able to enter the waters and ports of the strait edge. ${ }^{44}$ To prevent various undesirable situations, the presence of foreign fleets in the Malacca Strait also needs to be limited and monitored.

To prevent and control marine pollution in the Malacca Strait, international cooperation should be considered for environmental management. Arrangements for handling transboundary sea pollution are laid down in Part XII of the UNCLOS. Articles 197-237 of the UNCLOS have comprehensive regulations on the management of pollution control of the marine environment, which accommodates the legal basis for the formation, covering various forms of international cooperation. ${ }^{45}$ This is an important part because it regulates strait used as a strategic international navigation.

The cooperation in the handling and prevention of pollution in the Malacca Strait should be based on the principles of the ASEAN Charter, ${ }^{46}$ which in essence formulates an agreement that upholds the basic principles of respecting the sovereignty of each country and resolves disputes peacefully with enthusiasm for the ASEAN harmony. ${ }^{47}$ In accordance with the principle of consensus and noninterference, international cooperation should be carried out in the ASEAN to prevent, reduce, and control pollution from ships, as mandated by Article 43 (b) of the UNCLOS. The cooperation also requires the participation of every stakeholder of both the strait user country and the strait user company. In this course, however, the sovereignty of the coastal states should not be violated. ${ }^{48}$

Tripartite cooperation between Indonesia, Malaysia, and Singapore is based on trilateral agreement, which comprehensively cover shipping safety, security, environment, and economy (financing for the management of the Malacca Strait). In this agreement, strict limits on the involvement of third parties must be regulated to prevent third parties from dominating the Malacca Strait. ${ }^{49}$

The handling, prevention, and control of pollution in the Malacca Strait

43 UNCLOS art. 111.

44 AnWar, supra note 45.

45 Multilateral, regional, and technical assistance; environmental assessment and monitoring; international arrangements and national regulations to prevent, reduce, and control pollution of the marine environment; implementation; protection; ice-covered areas; responsibilities and obligations; sovereign immunity; and obligations under other conventions on the protection and preservation of the marine environment.

46 ASEAN Charter art. 2(2).

47 D. Rahmah, \& T. Handayani, Asean regional arbitration board: an alternative dispute resolution in the ASEAN region within the framework of the ASEAN economic community, 8(3) J. L. \& Judicial [JuRnal Hukum dan Peradilan] $333-52$ (2019).

48 UNCLOS art. 43.

49 ASEAN Charter art. 2(2). 
require international cooperation because marine pollution in the Malacca Strait is transboundary. Principle 24 of the Stockholm Declaration on the Human Environment states that: "International issues concerning environmental protection and improvement must be dealt with in a spirit of togetherness." Also, Principle 7 of the Rio 1992 Declaration on Environment and Development emphasizes that: "Countries must cooperate in the spirit of global partnership to preserve, protect, and restore the health and integrity of the earth's ecosystem."

While dealing with the environmental damage in the Malacca strait, we must pay attention to the various principles of environmental law stipulated in international conventions like precautionary principle, sustainable development, polluter pay principle, and preventive principle.

The UNCLOS should be a ground for determining the jurisdiction and responsibility of the marine environment. The UNCLOS has established the general principles of management because it prescribes the international legal structure within Integrated Coastal Zone Management. ${ }^{50}$

In accordance with Article 42, paragraph (1) and Article 43 (b) of the UNCLOS, Indonesia, Malaysia, and Singapore are required to make rules to use the strait for cruise shipping through the strait and must respect any regulations concerning the prevention, reduction, and control of pollution determined by international regulations relating to oil pollution, oil remnants, and other dangerous substances in the strait. ${ }^{51}$

Therefore, based on the provisions above, the user countries and countries bordering the strait should cooperate with each other through agreements for the procurement and maintenance of the necessary navigation and safety aids or the development of international shipping aids, as well as for the prevention, reduction, and control of pollution from ships in the strait.

The environmental management of the Malacca Strait through cooperation is also a mandate of Article 42, paragraph (1) to Article 43 (b) of the UNCLOS, which states that states bordering the strait are required to create rules relating to the use of the strait for shipping transit through the strait and must respect any regulations relating to preventing, reducing, and controlling pollution as determined by international regulations concerning oil pollution, residual oil, and other dangerous substances in the strait. ${ }^{52}$ Article 43 (b) formulated that the user states (strait) and countries bordering the strait must cooperate through agreement "to prevent, reduce, and

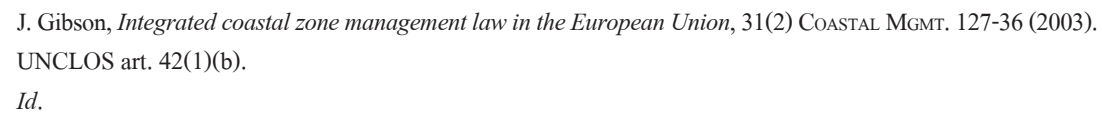


supervise pollution from ships." Liability compensation for ships that pollute should not only be limited to compensation, but also include environmental recovery costs.

The management of the Malacca Strait must be based on "the principle of freedom or sovereignty of States," which includes the principle of self-determination, the principle of permanent sovereignty over natural resources, the right of territorial integrity, and the prohibition of intervention. ${ }^{53}$ The implementation of these principles will not succeed without the support of the principle of solidarity as a moral foundation or as a form of compliance with international law. This will produce a basis for the obligation of the state to pay attention to the common interest.

\section{Conclusion}

With reference to the littoral states' agreement and the UNCLOS, the status of the Malacca Strait should no longer be an obstacle in the handling and prevention of marine pollution in the Malacca Strait. As members of the ASEAN, the littoral states should exhibit the same views and attitudes in handling and preventing sea pollution in the Malacca Strait. Tripartite cooperation, based on the principles of consensus and nonintervention, as contained in the ASEAN Charter, is an ideal form to manage the Malacca Strait. The spirit of the tripartite agreement needs to be developed, because the responsibility for handling and preventing marine pollution in the Malacca Strait is not just the responsibility of the littoral states. The involvement of third parties in international cooperation to overcome the problems that exist in the Malacca Strait needs to be regulated with strict guidelines to ensure that the cooperation carried out does not conflict with international law or national law of the littoral states. It will be mutually beneficial in the end.

Received: August 1, 2020

Modified: October 15, 2020

Accepted: November 15, 2020

53 P. van Dijk (ed.), Supervisory Mechanisms in International Economic Organisations: In the Perspective of a Restructuring of the International Economic Order (1984). 
